\title{
PENERAPAN ALGORITMA K-MEANS UNTUK ANALISIS DATA ULASAN DI SITUS TRIPADVISOR
}

\author{
Maya Nurjanah ${ }^{1}$, Toni Arifin ${ }^{2}$ \\ ${ }^{1}$ Universitas Adhirajasa Reswara Sanjaya \\ e-mail: mayanurj89@gmail.com \\ ${ }^{2}$ Universitas Adhirajasa Reswara Sanjaya \\ e-mail: toni.arifin@ars.ac.id
}

\begin{abstract}
Abstrak
Ulasan atau review merupakan suatu pendapat langsung dari seseorang. Review yaitu beberapa dari salah satu faktor yang menentukan keputusan seseorang, dengan menunjukkan bahwa orang dapat mengambil jumlah review sebagai indikator popularitas tempat atau nilai dari suatu tempat dengan mempengaruhi kemauan untuk mendatangi suatu tempat pariwisata. Penelitian ini membahas tentang Penerapan metode K-Means untuk review data travel . Dataset ini diambil langsung melalui halaman situs web $\mathrm{UCl}$ Machine Learning Repository dengan nama Review Travel dengan jumlah data sebanyak 980 record, terdri dari 10 variabel atau atribut yaitu galeri seni, klub dansa, bilah jus, restoran, museum, resort, taman atau tempat piknik, pantai, bioskop dan lembaga keagamaan. Proses cluster dibagi kedalam 2 (dua) cluster yaitu cluster rating tertinggi $(\mathrm{CO})$ dan cluster rating terendah $(\mathrm{C} 1)$. Sehingga diperoleh hasil pengelompokkan data ulasan atau review rating wisatawan cluster tertinggi berada pada $\mathrm{C} 0$ terdiri dari 3 objek wisata unggulan dengan rating tertinggi pada $\mathrm{C} 0$ yaitu Galeri seni dengan rating $=7,118$, Museum $=$ 5,396 dan Klub dansa $=4,783$. Sedangkan cluster terendah berada pada $\mathrm{C} 1$ terdiri dari 3 objek wisata unggulan dengan rating tertinggi yaitu Restoran dengan rating $=10,394$, Klub dansa $=$ 3,361 , Galeri seni $=3,233$.
\end{abstract}

Kata Kunci: Data Mining, Review Travel, Clustering, K-Means.

\begin{abstract}
A review or review is a direct opinion from someone. Reviews are some of the factors that determine a person's decision, by showing that people can take the number of reviews as an indicator of the popularity of a place or the value of a place by influencing the willingness to visit a tourism place. This study discusses the application of the K-Means method for reviewing travel data. This dataset is taken directly through the UCI Machine Learning Repository website page with the name Travel Review with a total data amount of 980 records, consisting of 10 variables or attributes, namely art galleries, dance clubs, juice bars, restaurants, museums, resorts, parks or picnic spots, beaches, cinemas and religious institutions. The cluster process is divided into 2 (two) clusters, namely the highest cluster rating (CO) and the lowest cluster rating (C1). So that the results of grouping data reviews or reviews the highest tourist rating cluster is at CO consisting of 3 leading tourist objects with the highest rating at CO, namely art galleries with rating $=7,118$, museum $=5,396$ and dance club $=4,783$. While the lowest cluster is at $C 1$ consisting of 3 leading tourist objects with the highest rating, namely restaurants with rating $=10.394$, dance clubs $=$ 3.361, art galleries $=3.233$.
\end{abstract}

Keywords: Data Mining, Travel Review, Clustering, K-Means. 


\section{Pendahuluan}

Pariwisata merupakan salah satu faktor yang sangat berpengaruh pada perkembangan perekonomian suatu daerah yang didalamnya memiliki tujuan dengan meningkatkan devisa negara, meningkatkan pendapatan pada suatu daerah, memperluas pada suatu kesempatan kerja, dan tidak mengeksploitasi kekayaan suatu alam (Dewi, Herdiani, \& Kusumo, 2018).

Wisatawan harus mengetahui terlebih dahulu kondisi pada objek wisata tersebut, sebelum para wisatawan ingin berkunjung ke suatu tempat objek wisata. Hal ini dapat dilihat dari ulasan atau review wisatawan yang sebelumnya pernah mengunjungi suatu tempat (R. Sari \& Hayuningtyas, 2019). Sehingga dapat diartikannya wisatawan adalah orang - orang yang berkunjung pada suatu tempat atau dengan maksud tujuan tertentu (R. W. Sari \& Hartama, 2018).

Perkembangan yang sangat pesat pada media online, tidak jarang wisatawan membagikan pengalaman dalam berwisata mereka pada situs web yang didalamnya menyediakan kolom komentar pada suatu tempat wisata, seperti pada situs web Tripadvisor. Situs web wisata seperti TripAdvisor cukup berperan penting bagi wisatawan sebagai salah satu bahan pertimbangan untuk mengunjungi suatu tempat yang diinginkan (Dewi et al., 2018).

Dengan beberapa situs yang muncul untuk memberikannya kemudahan bagi konsumen untuk memberikan ulasan (review) atau penilaian terhadap suatu entitas (Maulana \& Sibaroni, 2019).

Jika dilihat dari rata-rata ulasan atau review wisatawan pada tahun 2018. Khususnya ulasan rating wisatawan ke suatu objek wisata di negara asia timur. Tercatat ada 10 (sepuluh) objek wisata seperti Galeri seni, Klub dansa, Bilah jus, Restoran, Museum, Resort, Taman / Tempat piknik, Pantai, Bioskop dan Lembaga Keagamaan (Maulida, 2018).

Gambaran dari kepuasan konsumen untuk memilih suatu tempat. Banyaknya data yang yang tak terhingga dari berbagai konsumen dan beberapa ulasan atau review juga belum ditetapkan adanya rating maka membuat pihak travel mengalami kesulitan dalam mengklasifikasikan ulasan atau review kedalam rating dan mengetahui kekurangan dari tempat tersebut. Sehingga sangat penting adanya sistem yang membantu untuk mempercepat prediksi rating berdasarkan ulasan atau review wisatawan supaya tempat tersebut dapat melakukan evaluasi untuk ke depannya menjadi lebih baik. (Paramitha \& Dewi, 2019).

Penelitian terdahulu yang meneliti tentang pengelompokkan objek wisata unggul yang berbeda pada suatu tempat. Dimana perbedaanya terletak pada suatu objek penelitian yang akan diteliti. Tujuannya penelitian ini adalah untuk mengetahui suatu objek wisata unggulan di negara asia timur yang memiliki potensi yang paling tinggi dengan wisatawan memberikan ulasan berupa rating ke masing - masing tempat sehingga menemukan tempat yang unggul dengan peringkat yang tinggi. Pengelompokkan tersebut dapat menggunakan metode pengelompokkan dengan algoritma K-Means. Dengan data yang sudah dikelompokkan menggunakan algoritma K-Means diharapkan dapat mempermudah dalam mengelompokan ra.ting wisatawan dengan memberikan ulasan ke suatu objek wisata unggulan dengan peringkat yang tinggi, sehinggga dapat melakukan perbaikan sarana dan prasarana objek wisata unggulan yang dapat meningkatkan rating wisatawan pada objek wisata (Maulida, 2018).

Untuk memberikan rekomendasi suatu tempat berdasarkan ulasan atau review wisatawan, maka digunakanlah metode $K$ Means. Dengan metode tersebut, diharapkan akan menghasilkan pengelompokan objek wisata unggul pada suatu tempat (Pratama, Sari, \& Adikara, 2018).

Clustering adalah salah satu teknik dari salah satu fungsionalitas data mining, algoritma clustering adalah pengelompokkan dari sejumlah data menjadi suatu kelompok - kelompok data tertentu (Silalahi, 2018).

Untuk meringkas data atau sejumlah variabel menjadi lebih sedikit analisis cluster ini menjadi sangat berguna. Pada proses data ini dapat dilakukan dengan mengelompokan objek - objek berdasarkan kesamaan karakteristik tertentu diantara objek - objek yang akan diteliti (Anshori \& Nuraini, 2020).

Tujuan analisis cluster ini untuk mengelompokkan / mengklasifikasikan objek - objek berdasarkan karakteristik berdasarkan objek - objek, sehingga diketahui ciri khas dari masing - masing kelompok (Ary, 2015). 
Berdasarkan pemaparan latar belakang permasalahan, maka pada kesempatan kali ini akan dilakukan penelitian terhadap analisis data ulasan pada situs Tripadvisor. Data tersebut akan dikelompokkan dengan metode cluster dan algoritma K-Means dengan hasil yang diharapkan adalah berupa informasi mengenai pengelompokkan data ulasan berdasarkan rating tertinggi wisatawan pada suatu objek tempat wisata.

\section{Metode Penelitian}

Bagian ini menjelaskan tahapan demi tahapan yang penulis lakukan, dalam menyusun laporan ini agar lebih sistematis dan terarah sesuai dengan yang telah direncanakan.

\section{Tahapan Penelitian}

1. Pengumpulan data

Dalam tahap ini akan dijelaskan bagaimana data tersebut dikumpulkan dan darimana data tersebut diperoleh sehingga data tersebut dapat digunakan dalam eksperimen penelitian.

2. Pengolahan awal data

Pada tahap ini akan dijelaskan bagaimana pengolahan data untuk mendapatkan data yang sudah ditransformasikan agar sesuai dengan bentuk yang diinginkan.

3. Model yang diusulkan

Setelah dilakukan tahap pengolahan data pada tahap sebelumnya.

4. Eksperimen dan pengujian model

Selanjutnya dalam tahapan ini akan dilakukan pengujian terhadap model yang diusulkan untuk mendapatkan hasil kinerja dari model yang diusulkan.

5. Evaluasi dan validasi hasil

Pada tahapan penelitian terakhir ini akan dilakukan evaluasi terhadap eksperimen dan pengujian pada model yang diusulkan sehingga dapat mengetahui hasil kinerja dalam penelitian ini.

\section{Pengumpulan Data}

Dataset ini diambil langsung melalui halaman situs web $\mathrm{UCl}$ Machine Learning Repository dengan nama Review Travel dengan jumlah data sebanyak 980 record, terdri dari 10 variabel atau atribut, dan variable tujuan yaitu variabel yang dijadikan sebagai ulasan atau review wisatawan dengan memberikan nilai berupa rating pada suatu tempat. Variabel atau atribut nya yaitu galeri seni, klub dansa, bilah jus, restoran, museum, resort, taman atau tempat piknik, pantai, bioskop dan lembaga keagamaan.

Tabel 1.

Deskripsi atribut dataset Review Travel

\begin{tabular}{|c|c|c|c|}
\hline $\begin{array}{l}\mathrm{N} \\
\mathrm{O}\end{array}$ & Atribut & Deskripsi & $\begin{array}{l}\text { Tipe } \\
\text { Data }\end{array}$ \\
\hline 1 & $\begin{array}{l}\text { Galeri } \\
\text { Seni }\end{array}$ & $\begin{array}{lr}\text { Umpan } & \text { balik } \\
\text { pengguna } & \text { rata-rata } \\
\text { galeri seni } & \\
\end{array}$ & $\begin{array}{c}\text { Nume } \\
\text { rikal }\end{array}$ \\
\hline 2 & $\begin{array}{l}\text { Klub } \\
\text { Dansa }\end{array}$ & $\begin{array}{lr}\text { Umpan } & \text { balik } \\
\text { pengguna } & \text { rata-rata } \\
\text { klub dansa } & \end{array}$ & $\begin{array}{c}\text { Nume } \\
\text { rikal }\end{array}$ \\
\hline 3 & $\begin{array}{l}\text { Bilah } \\
\text { Jus }\end{array}$ & $\begin{array}{lr}\text { Umpan } & \text { balik } \\
\text { pengguna } & \text { rata-rata } \\
\text { bilah jus } & \end{array}$ & $\begin{array}{l}\text { Nume } \\
\text { rikal }\end{array}$ \\
\hline 4 & $\begin{array}{c}\text { Restora } \\
n\end{array}$ & $\begin{array}{lr}\text { Umpan } & \text { balik } \\
\text { pengguna } & \text { rata-rata } \\
\text { restoran } & \end{array}$ & $\begin{array}{c}\text { Nume } \\
\text { rikal }\end{array}$ \\
\hline 5 & $\begin{array}{c}\text { Museu } \\
\mathrm{m}\end{array}$ & $\begin{array}{lr}\text { Umpan } & \text { balik } \\
\text { pengguna } & \text { rata-rata } \\
\text { museum } & \\
\end{array}$ & $\begin{array}{l}\text { Nume } \\
\text { rikal }\end{array}$ \\
\hline 6 & Resort & $\begin{array}{lr}\text { Umpan } & \text { balik } \\
\text { pengguna } & \text { rata-rata } \\
\text { resort } & \end{array}$ & $\begin{array}{c}\text { Nume } \\
\text { rikal }\end{array}$ \\
\hline 7 & $\begin{array}{l}\text { Taman/ } \\
\text { Tempat } \\
\text { piknik }\end{array}$ & $\begin{array}{l}\text { Umpan balik } \\
\text { pengguna rata-rata } \\
\text { taman/tempat piknik }\end{array}$ & $\begin{array}{l}\text { Nume } \\
\text { rikal }\end{array}$ \\
\hline 8 & Pantai & $\begin{array}{lr}\text { Umpan } & \text { balik } \\
\text { pengguna } & \text { rata-rata } \\
\text { pantai } & \\
\end{array}$ & $\begin{array}{c}\text { Nume } \\
\text { rikal }\end{array}$ \\
\hline 9 & $\begin{array}{c}\text { Biosko } \\
p\end{array}$ & $\begin{array}{lr}\text { Umpan } & \text { balik } \\
\text { pengguna } & \text { rata-rata } \\
\text { bioskop } & \end{array}$ & $\begin{array}{l}\text { Nume } \\
\text { rikal }\end{array}$ \\
\hline 10 & $\begin{array}{c}\text { Lemba } \\
\text { ga } \\
\text { Keaga } \\
\text { maan }\end{array}$ & $\begin{array}{l}\text { Umpan balik } \\
\text { pengguna } \\
\text { rata-rata } \\
\text { lembaga } \\
\text { keagamaan }\end{array}$ & $\begin{array}{c}\text { Nume } \\
\text { rikal }\end{array}$ \\
\hline
\end{tabular}

\section{Pengolahan Awal Data}

Pada penelitian ini menggunakan dataset yang di dapatkan dari halaman situs web UCl Machine Learning Repository yaitu berupa dataset review travel sebanyak 980 record. Data yang sudah dijadikan sampel akan dilakukan pengolahan data dengan proses clustering dengan menggunakan algoritma $K$-Means sehingga didapatkanlah hasil pengelompokan data yang diinginkan. Adapun langkah dalam cluster dengan algoritma K-Means yaitu :

1. Menentukan pusat cluster awal. Menentukan centroid awal dilakukan secara acak dari data/objek yang tersedia sebanyak jumlah cluster $\mathrm{k}$. Nilai centroid awal pada penelitian ini dilakukan pemilihan secara acak.

2. Menghitng jarak dengan pusat cluster Untuk menghitung jarak setiap data yang ada terhadap pusat cluster dalam 
penelitian ini penulis menggunakan rumus Euclidean Distance.

3. Pengelompokan data Alokasikan masing-masing data ke dalam centroid yang paling terdekat. Dalam mengalokasikan kembali data ke dalam masing-masing cluster didasarkan pada perbandingan jarak antara data dengan centroid setiap cluster yang ada, data dialokasikan secara tegas ke dalam cluster yang mempunyai jarak ke centroid terdekat dengan data tersebut. Berikut ini merupakan hasil perbandingan jarak antara data dengan centroid setiap cluster yang ada berdasarkan perhitungan jarak dengan Euclidean Distance untuk iterasi 0.

4. Lakukan iterasi, kemudian tentukan posisi centroid baru dengan menggunakan persamaan.
5. Ulangi langkah 3 jika posisi centroid baru tidak sama. Pengecekan konvergensi dilakukan dengan membandingkan matriks group assignment pada iterasi sebelumnya dengan matrik group assignment.

6. padaiterasi yang sedang berjalan. Jika hasilnya sama maka algoritma kmeans cluster analysis sudah konvergen, tetapi jika berbeda maka belum konvergen sehingga perlu dilakukan iterasi berikutnya.

\section{Hasil dan Pembahasan}

Pada bagian ini akan dijelaskan pembahasan mengenai hasil penelitian yang penulis lakukan.

\subsection{Perhitungan Algoritma $K$-Means}

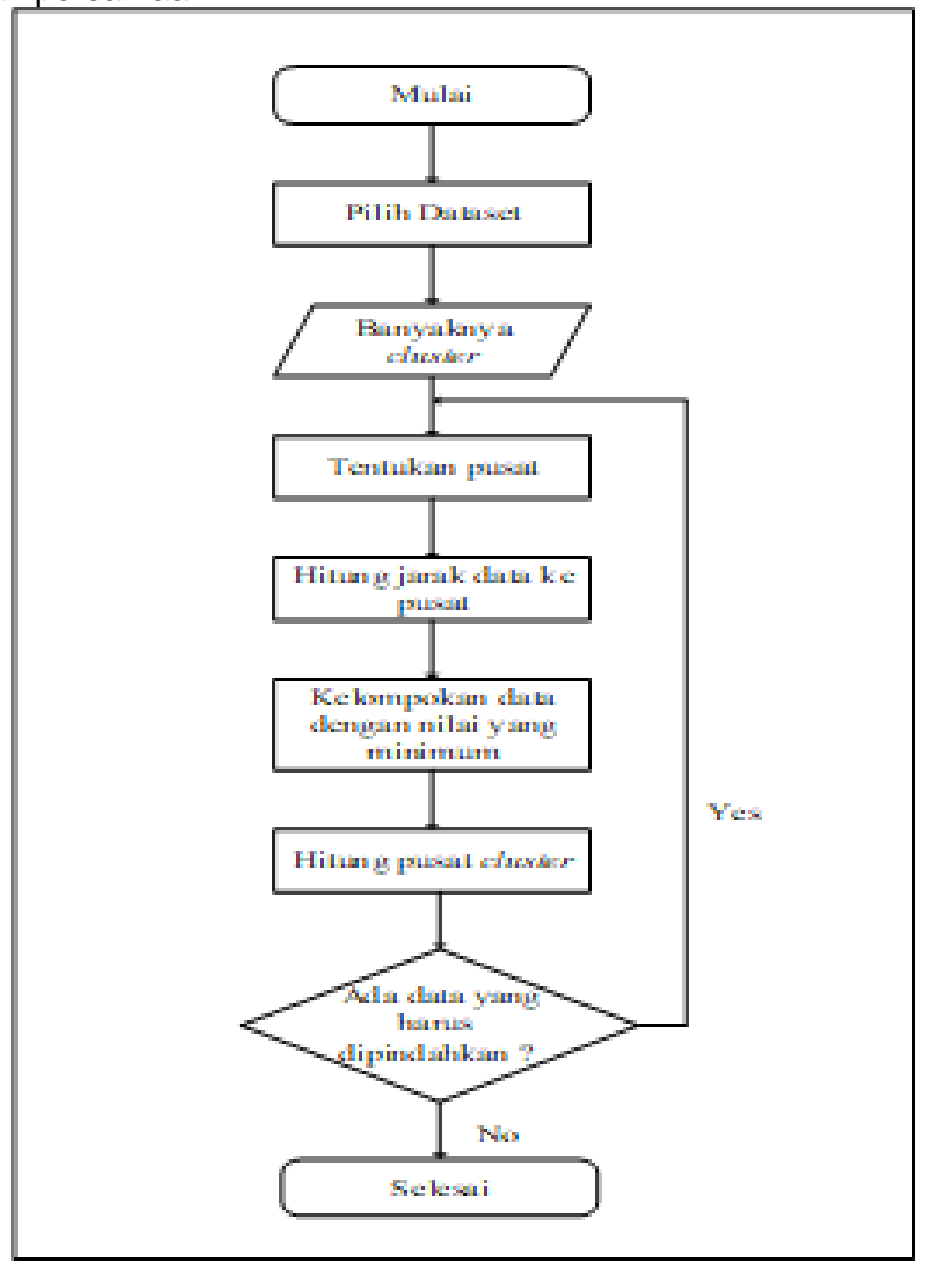

Gambar 1. Model yang Diusulkan

Langsung melalui halaman situs web $\mathrm{UCl}$ Machine Learning Repository dengan nama Review Travel. Sample data sebanyak 100 record dari laporan review atau ulasan rating wisatawan dengan memberikan rating ke suatu objek wisata unggulan.

Tahap pertama dalam algoritma $K$ Means adalah jumlah cluster, pada 
penelitian ini terdapat 2 cluster. Penentuan cluster awal dilakukan secara random dengan 10 atribut yaitu galeri seni, klub dansa, billah jus, restoran, museum, resort, taman / tempat piknik, pantai dan lembaga keagamaan. Berikut merupakan datasetnya terdapat pada Tabel 2.

Tabel 2.

Jumlah Ulasan / review rating wisatawan

\begin{tabular}{|c|c|c|c|c|c|c|c|c|c|c|}
\hline No & $\begin{array}{l}\text { Galeri } \\
\text { Seni }\end{array}$ & $\begin{array}{c}\text { Klub } \\
\text { Dansa }\end{array}$ & $\begin{array}{l}\text { Billah } \\
\text { Jus }\end{array}$ & $\begin{array}{l}\text { Restor } \\
\text { an }\end{array}$ & $\begin{array}{c}\text { Museu } \\
\mathrm{m}\end{array}$ & Resort & $\begin{array}{c}\text { Taman/Tempa } \\
\text { t Piknik }\end{array}$ & Pantai & Bioskop & $\begin{array}{c}\text { Lemba } \\
\text { ga } \\
\text { keaga } \\
\text { maan }\end{array}$ \\
\hline 1 & 0,93 & 1,8 & 2,29 & 0,62 & 0,8 & 2,42 & 3,19 & 2,79 & 1,82 & 2,42 \\
\hline 2 & 1,02 & 2,2 & 2,66 & 0,64 & 1,42 & 3,18 & 3,21 & 2,63 & 1,86 & 2,32 \\
\hline 3 & 1,22 & 0,8 & 0,54 & 0,53 & 0,24 & 1,54 & 3,18 & 2,8 & 1,31 & 2,5 \\
\hline 4 & 0,45 & 1,8 & 0,29 & 0,57 & 0,46 & 1,52 & 3,18 & 2,96 & 1,57 & 2,86 \\
\hline 5 & 0,51 & 1,2 & 1,18 & 0,57 & 1,54 & 2,02 & 3,18 & 2,78 & 1,18 & 2,54 \\
\hline 6 & 0,99 & 1,28 & 0,72 & 0,27 & 0,74 & 1,26 & 3,17 & 2,89 & 1,66 & 3,66 \\
\hline 7 & 0,9 & 1,36 & 0,26 & 0,32 & 0,86 & 1,58 & 3,17 & 2,66 & 1,22 & 3,22 \\
\hline 8 & 0,74 & 1,4 & 0,22 & 0,41 & 0,82 & 1,5 & 3,17 & 2,81 & 1,54 & 2,88 \\
\hline 9 & 1,12 & 1,76 & 1,04 & 0,64 & 0,82 & 2,14 & 3,18 & 2,79 & 1,41 & 2,54 \\
\hline 10 & 0,7 & 1,36 & 0,22 & 0,26 & 1,5 & 1,54 & 3,17 & 2,82 & 2,24 & 3,12 \\
\hline$\ldots$ & $\ldots$ & $\ldots$ & $\ldots$ & $\ldots$ & $\ldots$ & $\ldots$ & $\ldots$ & $\ldots$ & $\ldots$ & $\ldots$ \\
\hline 90 & 0,67 & 2,08 & 1,04 & 0,54 & 0,74 & 1,64 & 3,18 & 2,86 & 1,57 & 2,64 \\
\hline 91 & 1,38 & 1,12 & 0,72 & 0,53 & 0,88 & 1,36 & 3,18 & 2,81 & 1,79 & 3,26 \\
\hline 92 & 0,56 & 1,16 & 0,13 & 0,49 & 0,54 & 0,9 & 3,17 & 2,91 & 1,54 & 2,64 \\
\hline 93 & 1,1 & 2,04 & 2,45 & 0,54 & 1,44 & 2,28 & 3,19 & 2,74 & 1,63 & 2,42 \\
\hline 94 & 0,64 & 1,2 & 2,27 & 0,64 & 1,42 & 2,83 & 3,2 & 2,79 & 1,47 & 2,38 \\
\hline 95 & 0,99 & 2 & 2,13 & 0,64 & 1,82 & 2,6 & 3,19 & 2,67 & 1,5 & 2,46 \\
\hline 96 & 1,12 & 0,96 & 0,3 & 0,46 & 0,56 & 1,92 & 3,18 & 2,98 & 1,22 & 2,96 \\
\hline 97 & 0,9 & 1,44 & 2,34 & 0,55 & 0,94 & 2,14 & 3,19 & 2,79 & 1,79 & 2,82 \\
\hline 98 & 0,9 & 0,56 & 1,38 & 0,37 & 0,8 & 1,9 & 3,18 & 2,91 & 1,41 & 2,54 \\
\hline 99 & 1,02 & 0,886 & 2,7 & 0,53 & 1,02 & 1,78 & 3,19 & 2,86 & 2,14 & 2,78 \\
\hline 100 & 0,67 & 1,6 & 0,21 & 0,47 & 2,16 & 1,96 & 3,17 & 2,86 & 3,04 & 3,1 \\
\hline
\end{tabular}

Keterangan :

Rating 4 = Sangat Baik

Rating 3 = Sangat Bagus

Rating 2 = Rata - Rata

Rating $1=$ Buruk

Rating $0=$ Mengerikan
Tahap selanjutnya yaitu menentukan titik pusat awal dari cluster (centroid) yang dipilih secara random. Pada penelitian ini diambil dari data ke 20 dan 57.

Tabel 3. Centroid Awal

\begin{tabular}{|c|c|c|c|c|c|c|c|c|c|c|}
\hline Centroid & $\begin{array}{c}\text { Galeri } \\
\text { seni }\end{array}$ & $\begin{array}{c}\text { Klub } \\
\text { Dansa }\end{array}$ & $\begin{array}{c}\text { Bilah } \\
\text { Jus }\end{array}$ & Restoran & Museum & Resort & $\begin{array}{c}\text { Taman/Tempat } \\
\text { piknik }\end{array}$ & Pantai & Bioskop & $\begin{array}{c}\text { Lembaga } \\
\text { Keagamaan }\end{array}$ \\
\hline C0 & 0,8 & 1,04 & 2,1 & 0,58 & 1,18 & 1,98 & 3,19 & 2,93 & 1,22 & 2,48 \\
\hline C1 & 0,8 & 1,16 & 2,43 & 0,54 & 1,06 & 2,28 & 3,19 & 2,86 & 1,44 & 2,48 \\
\hline
\end{tabular}

Setelah menentukan centroid awal, maka tahap selanjutnya yaitu menghitung jarak setiap data yang ada ke centroid terdekat untuk menentukan cluster menggunakan rumus Euclidean distance. Berikut contoh perhitungan jarak ke setiap centroid

$$
\begin{aligned}
& \text { Data ke-1 cluster ke } 0 \\
& d(x i c 0)=\sqrt{a^{2}}+b^{2} \\
& =\sqrt{(0,93}-0,8)^{2}+(1,8-1,04)^{2}+(2,29- \\
& 2,1)^{2}+(0,62-0,58)^{2}+(0,8- \\
& 1,18)^{2}+(2,42-1,98)^{2}(3,19-
\end{aligned}
$$

$$
\begin{aligned}
& 3,19)^{2}+(2,79-2,93)^{2}+(1,82- \\
& 1,22)^{2}+(2,42-2,48)^{2} \\
& =\sqrt{0,13^{2}}+0,76^{2}+0,19^{2}+0,04^{2}+0,38^{2}+ \\
& 0,44^{2}+0+0,14^{2}+0,6^{2}+0,06^{2} \\
& =\sqrt{0,0169}+0,5776+0,0361+0,0016+ \\
& 0,1444+0,1936+0+0,0196+0,36+ \\
& 0,0036 \\
& =\sqrt{1,3534}=1,163 \\
& \hline
\end{aligned}
$$

Dari perhitungan data ke-1 dengan cluster ke-0 maka dihasilkan jarak 1,163. 
Data ke-1 cluster ke 1

$=\sqrt{(0,93}-0,8)^{2}+(1,8-1,16)^{2}+(2,29-$

$2,43)^{2}+(0,62-0,54)^{2}+(0,8-$

$1,06)^{2}+(2,42-2,28)^{2}(3,19-$

$3,19)^{2}+(2,79-2,86)^{2}+(1,82-$

$1,44)^{2}+(2,42-2,48)^{2}$

$=\sqrt{0,13^{2}}+0,64^{2}+\left(-0,14^{2}\right)+0,08^{2}+$

$\left(-0,26^{2}\right)+0,14^{2}+0+\left(-0,07^{2}\right)+0,38^{2}+$

$\left(-0,06^{2}\right)$

$=\sqrt{0,0169}+0,4096+0,0196+0,0064+$

$0,0676+0,0196+0+0,0049+0,1444$

$+0,0036$

$=\sqrt{0,6926}=0,832$

Dari perhitungan data ke-1 dengan cluster ke-1 maka dihasilkan jarak 0,832.

Hasil perhitungan tersebut yaitu jarak data perhitungan tersebut yaitu jarak data ke-1 dengan cluster ke-0 sebesar 1,163 jarak dan data ke-1 dengan cluster ke-1 sebesar 0,832 . Berikut Tabel IV.4 yang merupakan perhitungan lengkap dari iterasi ke-1.

Tabel 4.

Hasil perhitungan dengan menggunakan rumus Euclidean pada iterasi ke-1

\begin{tabular}{|c|c|c|c|c|}
\hline \multirow{2}{*}{$\begin{array}{l}\text { Data } \\
\text { ke-i }\end{array}$} & \multicolumn{2}{|c|}{ Jarak ke centroid } & \multirow{2}{*}{$\begin{array}{c}\text { Jarak } \\
\text { Terdekat }\end{array}$} & \multirow{2}{*}{$\begin{array}{c}\text { Cluster } \\
\text { yang } \\
\text { diikuti }\end{array}$} \\
\hline & $\mathrm{CO}$ & C1 & & \\
\hline 1 & $\begin{array}{l}1,1633572 \\
11\end{array}$ & $\begin{array}{l}0,8322259 \\
31\end{array}$ & $\begin{array}{l}0,83222 \\
5931\end{array}$ & C1 \\
\hline 2 & $\begin{array}{l}1,9324595 \\
73\end{array}$ & $\begin{array}{l}1,5452507 \\
9\end{array}$ & $\begin{array}{l}1,54525 \\
079\end{array}$ & C1 \\
\hline 3 & $\begin{array}{l}1,9423696 \\
87\end{array}$ & $\begin{array}{l}2,2625649 \\
16\end{array}$ & $\begin{array}{l}1,94236 \\
969\end{array}$ & $\mathrm{CO}$ \\
\hline 4 & $\begin{array}{l}2,2302914 \\
61\end{array}$ & $\begin{array}{l}2,4943135 \\
33\end{array}$ & $\begin{array}{l}2,23029 \\
146\end{array}$ & $\mathrm{CO}$ \\
\hline 5 & $\begin{array}{l}1,0560303 \\
03\end{array}$ & $\begin{array}{l}1,4229546 \\
73\end{array}$ & $\begin{array}{l}1,05603 \\
03\end{array}$ & $\mathrm{CO}$ \\
\hline 6 & $\begin{array}{l}2,0962347 \\
2\end{array}$ & $\begin{array}{l}2,3732677 \\
89\end{array}$ & $\begin{array}{l}2,09623 \\
472\end{array}$ & $\mathrm{CO}$ \\
\hline 7 & $\begin{array}{l}2,1092415 \\
7\end{array}$ & $\begin{array}{l}2,4441153 \\
82\end{array}$ & $\begin{array}{l}2,10924 \\
157\end{array}$ & $\mathrm{CO}$ \\
\hline 8 & $\begin{array}{l}2,0817540 \\
68\end{array}$ & $\begin{array}{l}2,4085472 \\
8\end{array}$ & $\begin{array}{l}2,08175 \\
407\end{array}$ & $\mathrm{CO}$ \\
\hline 9 & $\begin{array}{l}1,4009282 \\
64\end{array}$ & $\begin{array}{l}1,5783535 \\
73\end{array}$ & $\begin{array}{l}1,40092 \\
826\end{array}$ & $\mathrm{CO}$ \\
\hline 10 & $\begin{array}{l}2,3468489 \\
51\end{array}$ & $\begin{array}{l}2,6086969 \\
93\end{array}$ & $\begin{array}{l}2,34684 \\
895\end{array}$ & $\mathrm{CO}$ \\
\hline & & & & \\
\hline 90 & $\begin{array}{l}1,6389020 \\
72\end{array}$ & $\begin{array}{l}1,8303005 \\
22\end{array}$ & $\begin{array}{c}1,63890 \\
207\end{array}$ & C0 \\
\hline 91 & $\begin{array}{l}1,9162202 \\
38\end{array}$ & $\begin{array}{l}2,2078269 \\
86\end{array}$ & $\begin{array}{c}1,91622 \\
024\end{array}$ & C0 \\
\hline 92 & $\begin{array}{l}2,3802940 \\
99\end{array}$ & $\begin{array}{l}2,7501636 \\
31\end{array}$ & $\begin{array}{c}2,38029 \\
41\end{array}$ & $\mathrm{CO}$ \\
\hline 93 & $\begin{array}{l}1,2567816 \\
04\end{array}$ & $\begin{array}{l}1,0311643 \\
9\end{array}$ & $\begin{array}{c}1,03116 \\
439\end{array}$ & C1 \\
\hline 94 & $\begin{array}{l}0,9777525 \\
25\end{array}$ & $\begin{array}{l}0,7147027 \\
35\end{array}$ & $\begin{array}{c}0,71470 \\
274\end{array}$ & C1 \\
\hline
\end{tabular}

\begin{tabular}{|c|l|l|c|c|}
\hline 95 & 1,3793476 & 1,2497199 & 1,24971 & $\mathrm{C} 1$ \\
& 72 & 69 & 997 & \\
\hline 96 & 1,9913312 & 2,3108007 & 1,99133 & $\mathrm{C} 0$ \\
& 13 & 27 & 121 & \\
\hline 97 & 0,8785214 & 0,6112282 & 0,61122 & $\mathrm{C} 1$ \\
& 85 & 72 & 827 & \\
\hline 98 & 0,9969453 & 1,3116783 & 0,99694 & $\mathrm{C} 0$ \\
& 35 & 14 & 533 & \\
\hline 99 & 1,1867181 & 1,0080178 & 1,00801 & $\mathrm{C} 1$ \\
& 64 & 57 & 786 & \\
\hline 100 & 2,9287540 & 3,0661050 & 2,92875 & $\mathrm{C} 0$ \\
& 01 & 21 & 4 & \\
\hline
\end{tabular}

Selanjutnya kelompokan data sesuai dengan jarak cluster terdekat. Dari data yang sudah dikelompokan akan didapat centroid baru dari hasil rata - rata setiap cluster. Lakukan langkah tersebut sampai nilai centroid tidak mengalami perubahan.

\subsection{Validasi Hasil}

Berdasarkan Uji DBI dapat ditentukan seberapa baik clustering sudah dilakukan dengan parameter semakin kecil atau minimal nilai uji maka hasil clustering yang didapat semakin baik. Setelah dilakukan percobaan menggunakan Rapidminer dengan pemodelan $\mathrm{K}=2$ sampai dengan $\mathrm{K}=10$, didapatkan nilai cluster optimal terdapat pada $\mathrm{K}=2$ dengan nilai $\mathrm{DBI}$ 0,101 .

Tabel 5.

Hasil DBI pengujian K2 sampai K10 pada aplikasi Rapidminer

\begin{tabular}{|l|l|}
\hline Cluster & Hasil \\
\hline $\mathrm{K}=2$ & 0,101 \\
\hline $\mathrm{K}=3$ & 0,147 \\
\hline $\mathrm{K}=4$ & 0,164 \\
\hline $\mathrm{K}=5$ & 0,171 \\
\hline $\mathrm{K}=6$ & 0,175 \\
\hline $\mathrm{K}=7$ & 0,171 \\
\hline $\mathrm{K}=8$ & 0,172 \\
\hline $\mathrm{K}=9$ & 0,165 \\
\hline $\mathrm{K}=10$ & 0,172 \\
\hline
\end{tabular}

Pada penentuan cluster menggunakan matriks Devies Bouldin Index digunakan data centroid dari iterasi terakhir pada proses clustering. Berikut merupakan centroid akhir dari hasil clustering.

\subsection{Pembahasan}

Rapidminer, maka menghasilkan informasi sebagai berikut :

1. Pada cluster 0 terdiri dari 959 items dengan tempat pariwisata yang paling unggul di cluster 0 dengan rating tertinggi di masing - masing tempat, diantaranya Galeri seni dengan rating = 
7,118 , Klub dansa $=4,783$, Billah jus $=$ 3,305 , Restoran $=2,994$, Museum $=$ 5,396, Resort $=3,553$, Tempat $/$ tempat piknik $=3,714$, Pantai $=4,036$, Bioskop $=4,390$, Lembaga keagamaan $=2,678$.

2. Pada cluster 1 terdiri dari 21 items dengan tempat pariwisata yang paling unggul di cluster 1 dengan rating tertinggi di masing - masing tempat, diantaranya Galeri seni dengan rating = 3,233 , Klub dansa $=3,361$, Billah jus $=$ 1,353 , Restoran $=10,394$, Museum $=$ 2,470, Resort $=2,033$, Tempat $/$ tempat piknik $=2,436$, Pantai $=-1,564$, Bioskop $=1,318$, Lembaga keagamaan $=0,749$. Berdasarkan uraian tersebut, maka dapat disimpulkan bahwa cluster tertinggi berada pada cluster 0 . Sehingga tempat yang menjadi unggul dengan rating tertinggi pada cluster 0 yaitu Galeri seni, Museum, dan Klub dansa. Sedangkan cluster terendah berada pada cluster 1 . Sehingga tempat yang menjadi unggul dengan rating tertinggi pada cluster 1 yaitu Restoran, Klub dansa, dan Galeri seni.

\section{Kesimpulan}

1. Untuk mengetahui suatu data ulasan atau review dengan rating tertinggi pada suatu tempat pariwisata maka dapat menerapkan metode clustering $K$ Means, data diolah menggunakan Ms. Excel untuk ditentukan nilai centroid dalam 2 cluster yaitu cluster rating tertinggi $(\mathrm{C} 0)$ dan cluster rating terendah (C1).

2. Berikut hasil pengelompokkan data ulasan atau review rating wisatawan $\mathrm{C} 0$ terdiri dari 3 objek wisata unggulan dengan rating tertinggi pada cluster 0 yaitu Galeri seni dengan rating $=7,118$, Museum $=5,396$ dan Klub dansa $=$ 4,783. Dan pada cluster 1 terdiri dari 3 objek wisata unggulan dengan rating tertinggi pada cluster 1 yaitu Restoran dengan rating $=10,394$, Klub dansa $=$ 3,361 , Galeri seni $=3,233$.

\section{Saran}

1. Eksperimen review travel dapat menggunakan algoritma clustering yang lain seperti K-Medoids dan Fuzzy CMeans sehingga mendapatkan hasil yang lebih baik.

2. Dapat mengembangkan penelitian dengan menambahkan atribut waktu seperti tanggal dan bulan untuk penambahan atribut yang dijadikan untuk mengetahui waktu ulasan atau review rating wisatawan pada dataset review travel.

\section{Referensi}

Anshori, I. F., \& Nuraini, Y. (2020). Pengelompokan Data Kecelakaan Lalu Lintas Di Kota Tasikmalaya Menggunakan Algoritma K-Means. 2(1), 118-127.

Ary, M. (2015). Pengklasifikasian Karakteristik Mahasiswa Baru Dalam Memilih Program Studi Menggunakan Analisis Cluster. II(1), 181-188.

Dewi, Herdiani, \& Kusumo, D. S. (2018). Multi-Aspect Sentiment Analysis Komentar Wisata TripAdvisor dengan Rule-Based Classifier ( Studi Kasus: Bandung Raya ). EProceeding of Engineering, 5(1), 1589-1596.

Maulana, A., \& Sibaroni, Y. (2019). Klasifikasi Sentimen Ulasan Tempat Makan Berbahasa Indonesia Menggunakan Lexicon dan Improved Naive Bayes. Ind. Journal on Computing, 4(3), 107-116. https://doi.org/10.21108/indojc.2019 .4.3.369

Maulida, L. (2018). Kunjungan Wisatawan Ke Objek Wisata Unggulan Di Prop . DKI Jakarta Dengan K-Means. JISKa (Jurnal Informatika Sunan Kalijaga), 2(3), 167-174.

Pratama, N. D., Sari, Y. A., \& Adikara, P. P. (2018). Analisis Sentimen Pada Review Konsumen Menggunakan Metode Naive Bayes Dengan Seleksi Fitur Chi Square Untuk Rekomendasi Lokasi Makanan Tradisional. Jurnal Pengembangan Teknologi Informasi Dan IImu Komputer, 2(9), 2982-2988.

Paramitha, D. T. A., \& Dewi, I. C. \& C. (2019). Prediksi Rating Otomatis Berdasarkan Review Restoran pada Aplikasi Zomato dengan menggunakan Extreme Learning 
Machine ( ELM ). Jurnal

Pengembangan Teknologi Informasi Dan IImu Komputer, 3(5), 4687-4693.

Sari, R., \& Hayuningtyas, R. Y. (2019). Penerapan Algoritma Naive Bayes Untuk Analisis Sentimen Pada Wisata TMII Berbasis Website. IJSE - Indonesian Journal on Software Engineering, 5(2), 51-60.

Sari, R. W., \& Hartama, D. (2018). Data Mining: Algoritma K-Means Pada Pengelompokkan Wisata Asing ke Indonesia Menurut Provinsi. 322326.

Silalahi, M. (2018). Analisis Clustering Menggunakan Algoritma K-Means Terhadap Penjualan Produk Pada PT. Batamas Niaga Jaya. Computer Based Information System Journal, 06(2), 20-35. 